\title{
DIFFERENCES IN EFFECTIVENESS TOOTHPASTE GEL FORMULATION WITH PASTE IN MAINTAINING NORMAL SALIVARY PH \\ Randy Fernandes ${ }^{1}$, Nila Kasuma ${ }^{2}$, Vivi Triana ${ }^{3}$ \\ ${ }^{1}$ Faculty of Dentistry Andalas University \\ ${ }^{2}$ Department of Oral Biology Faculty of Dentistry Andalas University \\ ${ }^{3}$ Faculty of Public Health Andalas University
}

\begin{abstract}
Saliva is oral fluids consisted of mixture of secretions from major and minor salivary glands. Salivary $p H$ ranges from 5.6 to 7.0 with average in 6.7. Teeth brushing could change salivary $\mathrm{pH}$. Toothpaste which distribute among our society nowadays is either gel or paste contain xylitol or sorbitol. Xylitol and sorbitol are able to stimulate the secretion of saliva therefore increase buffering capacity and $\mathrm{pH}$ of saliva. This research is an experiment with pre-test post-test study design. This research used 36 samples. The measurement of the $\mathrm{pH}$ of saliva was performed five times: before brushing, 5, 10, 30 and 60 minutes after brushing with toothpaste. Result showed significant differences in before brushing with 5 minutes after brushing, and 5 minutes with 10 minutes after brushing. While in 10 minutes with 30 minutes after brushing and 60 minutes with 30 minutes after brushing there was no significant differences. The average $p H$ of saliva by gel formulation is more fluctuating than $\mathrm{pH}$ saliva by paste formulation which tends to decline as time changes in normal circumstances and more stable to maintain normal salivary $\mathrm{pH}$. The conclusion of this research is toothpaste with paste formulation is more stable in maintaining normal $\mathrm{pH}$ of saliva compared to toothpaste with gel formulation
\end{abstract}

Keywords : salivary $\mathrm{pH}$, toothpaste gel formulation, toothpaste paste formulation

Affiliasi penulis: ${ }^{1}$ Faculty of Dentistry Andalas University

Korespondensi : Randy Fernandes

Email : adxcoel007@gmail.com

\section{PENDAHULUAN}

Pasta gigi adalah produk oral yang digunakan untuk membersihkan gigi dari sisa makanan, menghilangkan plak dan bau mulut serta memperindah penampilan estetik gigi. Pada masa lalu, penggunaan pasta gigi terbatas hanya sebagai kosmetik. Tetapi dalam beberapa tahun terakhir ini, banyak dibuat pasta gigi yang mempunyai efek untuk mengobati penyakit mulut dan mencegah karies gigi. $^{1,2}$

Pasta gigi memiliki tujuh
persyaratan utama, yaitu mampu
membersihkan gigi (menghilangkan sisa makanan, plak dan noda), meninggalkan sensasi bersih dan segar pada mulut setelah berkumur, harga terjangkau sehingga mudah didapat oleh berbagai kalangan, tidak boleh membahayakan pengguna (aman dalam penggunaan), stabil selama penyimpanan, bahan abrasif yang digunakan sesuai dengan enamel dan dentin dan telah teruji secara klinis. ${ }^{3}$

Formula pasta gigi secara umum terdiri atas bahan abrasif, bahan pengikat (binders), surfaktan, humektan (xilitol 
atau sorbitol), pemanis, perasa, pewarna, pengawet, zat aktif dan zat tambahan lain. Berdasarkan penelitian yang dilakukan oleh Sari tahun 2011 menemukan bahwa perbedaan jenis humektan dalam pasta gigi yaitu xilitol dan sorbitol dapat mempengaruhi perubahan bahkan peningkatan $\mathrm{pH}$ saliva pada pasien Diabetes Melitus. Xilitol dan sorbitol mempunyai sifat menstimulasi aliran saliva sehingga dapat meningkatkan laju saliva yang kemudian senyawa bikarbonat dalam saliva akan mengalami peingkatan dan akhirnya terjadi peningkatan kapasitas penyangga saliva. ${ }^{4}$

Basis gel toothpaste dipengaruhi oleh komposisi gelling agent dan humektan karena sebagian besar komponen penyusun dari sediaan gel toothpaste adalah gelling agent dan humektan. Sediaan pasta gigi yang beredar dipasaran ada 2 jenis yaitu sediaan pasta dan sediaan gel (transparan). Pasta gigi gel transparan (gel toothpaste) mempunyai presentase humektan mencapai $80 \%$ dari jumlah total formula sedangkan sediaan pasta hanya memiliki presentasi sekitar 40$60 \%$ dari total formulasinya. Hal ini didasarkan pada sifat gelling agent sebagai agen pengikat (binder) yang bertanggung jawab dalam menjaga konstituen padatan dan cairan dalam suatu bentuk pasta halus sedangkan humektan berperan dalam peningkatan stabilitas gel toothpaste dengan cara mempertahankan kelembaban sistem gel toothpaste karena dapat mengikat air dari lingkungan supaya masuk ke dalam sistem sediaan. ${ }^{5}$ Penelitian yang dilakukan di India tahun 2013 mengenai perbedaan jumlah konsentrasi komposisi dalam pasta gigi dapat menentukan bentuk dari sediaan pasta gigi. Penelitian ini menunjukan hasil bahwa $\mathrm{pH}$ pasta gigi sediaan pasta lebih basa dari pada $\mathrm{pH}$ sediaan gel dengan $\mathrm{pH}$ 9,64 untuk sediaan pasta dan $\mathrm{pH} 7,08$ untuk sediaan gel.6 AJM Ligtenberg di Belanda tahun 2006 menguji beberapa jenis pasta gigi dan mendapatkan hasil bahwa sediaan pasta memiliki efek yang bagus dalam mempertahankan $\mathrm{pH}$ saliva sebelum kembali ke keadaan normal sedangkan pasta gigi sediaan pasta dengan penambahan sensasi mentol memiliki efek tidak begitu baik dalam merangsang sekresi saliva setelah menggosok gigi karena sensasi mentol yang dihasilkan oleh pasta gigi tersebut menyebabkan efek lokal anastesi sehingga menghambat kelenjar saliva untuk mensekresikan saliva meskipun $\mathrm{pH}$ saliva akan tetap mengalami kenaikan. Kandungan mentol atau sensasi dingin juga banyak 
ditambahkan kepada pasta gigi sediaan gel khususnya. Ketika sekresi saliva berkurang maka senyawa bikarbonat sebagai senyawa penyangga didalam saliva juga akan berkurang, hal ini menyebabkan $\mathrm{pH}$ saliva kurang optimum diperoleh setelah menggunakan sediaan yang memiliki efek mentol. ${ }^{7}$

Saliva adalah cairan kompleks yang dihasilkan oleh glandula salivarius seperti glandula parotis, submandibula, sublingual, labial, bukal dan palatal. Saliva memiliki fungsi antara lain melindungi jaringan di dalam rongga mulut dengan cara pembersihan secara mekanis untuk mengurangi akumulasi plak pada permukaan gigi, lubrikasi elemen gigi-geligi, pengaruh penyangga, agregasi bakteri yang dapat menghambat kolonisasi mikroorganisme, aktifitas antibakterial, membantu fungsi pengecapan, pencernaan dan membantu perbaikan jaringan. Fungsi saliva sebagai perlindungan dipengaruhi oleh komposisi, viskositas, $\mathrm{pH}$ serta susunan ion serta protein saliva.8-10 $\mathrm{pH}$ dan kapasitas penyangga saliva ditentukan oleh susunan kuantitatif dan kualitatif elektrolit di dalam saliva terutama susunan bikarbonat, karena susunan bikarbonat sangat konstan dalam saliva dan berasal dari kelenjar saliva. PH saliva dalam keadaan normal antara 5,6-7,0 dengan rata-rata $\mathrm{pH}$ 6,7. Beberapa faktor yang menyebabkan terjadinya perubahan pada $\mathrm{pH}$ saliva antara lain rata-rata kecepatan aliran saliva, mikroorganisme rongga mulut dan kapasitas penyangga saliva. $\mathrm{pH}$ saliva yang optimum untuk menghambat pertumbuhan bakteri adalah 6,5-7,5. Apabila rongga mulut $\mathrm{pH}$-nya rendah antara 4,5-5,5 akan memudahkan pertumbuhan kuman asidogenik seperti Streptococcus mutans dan Lactobacillus. ${ }^{9}$ $\mathrm{pH}$ saliva dan kapasitas penyangga saliva dapat dipengaruhi oleh irama siang dan malam (circadian sickle), diet dan perangsangan kecepatan sekresi. Pengaruh irama siang dan malam menunjukkan bahwa $\mathrm{pH}$ dan kapasitas penyangga saliva akan turun ketika bangun pagi, tetapi kemudian akan segera naik setelah 15 menit. 5 menit setelah makan PH saliva akan tinggi karena adanya rangsangan mekanis, namun setelah 30-60 menit PH saliva akan kembali kepada keadaan normal. Pada malam hari, $\mathrm{pH}$ dan kapasitas penyangga saliva akan meningkat, tetapi menjelang tengah malam akan turun kembali. ${ }^{9}$

Tujuan dilakukan penelitian ini untuk melakukan uji $\mathrm{pH}$ saliva sebelum kembali ke keadaan normal setelah menggosok gigi dengan menggunakan pasta gigi sediaan gel dan pasta gigi sediaan pasta. 
METODE PENELITIAN

Penelitian ini merupakan penelitian eksperimental dengan pendekatan pretest posttest study. Penelitian ini dilakukan pada tanggal $17-$ 23 Februari 2016, dimulai pada pukul 10.00-13.00 WIB. Sampel yang digunakan dalam penelitian ini berjumlah 36 orang, dan keseluruhan sampel adalah mahasiswa Fakultas Kedokteran Gigi Universitas Andalas angkatan 2012 dan 2014.

Pada hari pertama, dilakukan pengumpulan subjek penelitian yang sesuai dengan kriteria inklusi dan eksklusi, serta pengisian informed consent. Kemudian hari berikutnya dilakukan pengukuran $\mathrm{pH}$ saliva sebelum menggosok gigi, setelah itu sampel diinstruksikan menggosok dengan sediaan pasta atau gel. Setelah menggosok gigi selama 2 menit, sample diinstruksikan kembali mengumpulkan saliva dengan metode spitting pada menit ke-5, 10, 30 dan 60. Penelitian dilakukan selama 3 hari dengan setiap harinya dilakukan penelitian kepada 12 sampel. sampel dibagi menjadi 2 kelompok sampel yaitu 18 sampel menggunakan pasta gigi sediaan gel dan 18 sampel menggunakan sediaan pasta.

$\mathrm{pH}$ saliva kemudian dicatat dan hasilnya diolah dan ditabulasi dan dilakukan uji normalitas dengan metode Shapiro Wilk. Kemudian dilakukan uji beda (uji t berpasangan dan uji t tidak berpasangan).

\section{HASIL PENELITIAN}

Analisis univariat dilakukan pada masing masing kelompok perlakuan dengan uji normalitas Saphiro Wilk untuk mengetahui apakah data terdistribusi secara normal. Hasil uji normalitas dari setiap kelompok data memiliki nilai $\mathrm{p}$ yang lebih besar dari $0,05(\mathrm{p}>0,05)$ yang berarti data pada tiap kelompok perlakuan terdistribusi normal.

Hasil dari Uji t tidak berpasangan pada perlakuan sampel dengan pasta gigi sediaan gel menunjukan terdapat perbedaan yang signifikan $(\mathrm{p}<0,05)$ antara $\mathrm{pH}$ saliva sebelum menggosok gigi dengan sediaan gel dengan 5 menit setelah menggunakan sediaan pasta gigi gel. Namun tidak terdapat perbedaan yang signifikan $(\mathrm{p}>0,05)$ pada kelompok waktu yang lain. Dan pada sediaan pasta gigi sediaan pasta diketahui bahwa tidak terdapat perbedaan yang signifikan ( $\mathrm{p}>$ 0,05) antara $\mathrm{pH}$ saliva sebelum dan setelah menggunakan pasta gigi sediaan pasta sampai menit ke 60 .

$$
\text { Kemudian dilakukan uji } \mathrm{T}
$$
berpasangan untuk mengetahui selisih masing-masing sediaan dan didapat hasil bahwa terdapat perbedaan yang 
bermakna $(\mathrm{p}<0,05)$ antara rata-rata selisih $\mathrm{pH}$ saliva setelah menggunakan kedua jenis sediaan pasta gigi pada menit ke-5 dan sebelum menggunakan kedua jenis sediaan pasta gigi, serta terdapat perbedaan yang bermakna $(\mathrm{p}<0,05)$ antara rata-rata selisih $\mathrm{pH}$ saliva pada menit ke-10 dan menit ke-5 setelah sampel yang menggunakan pasta gigi sediaan gel dan pasta gigi sediaan pasta. Namun, tidak terdapat perbedaan yang bermakna $(\mathrm{p}>0,05)$ antara rata-rata selisih pH saliva pada menit ke-30 dan menit ke-10 serta pada menit ke-60 dan menit ke- 30 setelah sampel yang menggunakan pasta gigi sediaan gel dan pasta gigi sediaan pasta.

Tabel 1 Rata-rata selisih $\mathrm{pH}$ saliva setelah menggunakan pasta gigi sediaan gel dan pasta

\begin{tabular}{|c|c|c|c|c|c|c|}
\hline \multirow{2}{*}{ Selisih $\mathrm{pH}$ Saliva } & \multirow{2}{*}{ Sediaan } & \multirow{2}{*}{$\mathrm{n}$} & \multirow{2}{*}{ Mean \pm SD } & \multirow{2}{*}{$p$} & \multicolumn{2}{|c|}{$95 \% \mathrm{CI}$} \\
\hline & & & & & Lower & Upper \\
\hline \multirow{2}{*}{$\begin{array}{l}\text { Selisih } \mathrm{pH} \text { setelah } 5 \\
\text { menit - sebelum }\end{array}$} & Gel & 18 & $0,18 \pm 0,26$ & \multirow[b]{2}{*}{$0,013^{*}$} & \multirow[b]{2}{*}{0,54} & \multirow[b]{2}{*}{0,43} \\
\hline & Pasta & 18 & $-0,06 \pm 0,30$ & & & \\
\hline \multirow{2}{*}{$\begin{array}{l}\text { Selisih } \mathrm{pH} \text { setelah } 10 \\
\text { menit }-5 \text { menit }\end{array}$} & Gel & 18 & $-0,07 \pm 0,24$ & \multirow{2}{*}{$0,023^{*}$} & \multirow{2}{*}{$-0,36$} & \multirow{2}{*}{$-0,03$} \\
\hline & Pasta & 18 & $0,12 \pm 0,26$ & & & \\
\hline \multirow{2}{*}{$\begin{array}{l}\text { Selisih } \mathrm{pH} \text { setelah } 30 \\
\text { menit - } 10 \text { menit }\end{array}$} & Gel & 18 & $0,05 \pm 0,25$ & \multirow{2}{*}{0,075} & \multirow{2}{*}{$-0,02$} & \multirow{2}{*}{0,34} \\
\hline & Pasta & 18 & $-0,11 \pm 0,27$ & & & \\
\hline \multirow{2}{*}{$\begin{array}{l}\text { Selisih } \mathrm{pH} \text { setelah } 60 \\
\text { menit - } 30 \text { menit }\end{array}$} & Gel & 18 & $-0,09 \pm 0,24$ & \multirow[b]{2}{*}{0,271} & \multirow[b]{2}{*}{$-0,26$} & \multirow[b]{2}{*}{0,07} \\
\hline & Pasta & 18 & $0,004 \pm 0,24$ & & & \\
\hline
\end{tabular}

\section{PEMBAHASAN}

Rata-rata $\mathrm{pH}$ saliva sebelum sampel menggunakan pasta gigi sediaan gel adalah 6,98. Hal ini sesuai dengan teori yang menyatakan bahwa $\mathrm{pH}$ saliva dalam keadaan normal berkisar antara 5,6-7,0 dengan rata-rata $\mathrm{pH} 6,7 .{ }^{9}$ Dalam teori lain menyebutkan bahwa $\mathrm{pH}$ saliva yang tidak dirangsang biasanya bersifat asam dengan kisaran pH antara 6,4-6,9. ${ }^{36}$ Terjadinya sedikit perbedaan nilai pada $\mathrm{pH}$ saliva sebelum distimulasi dapat disebabkan oleh beberapa faktor perancu yang tidak bisa dikendalikan dalam penelitian ini. Faktor-faktor tersebut diantaranya adalah diet, aktivitas fisik, status psikologis dan stres. ${ }^{10,28}$ Rata-rata pH saliva pada menit ke-5 setelah sampel menggunakan pasta gigi sediaan gel adalah 7,16. pH saliva pada menit ke-5 mengalami kenaikan yang signifikan dari pH saliva sebelum sampel menggunakan pasta gigi sediaan gel. Hal ini sesuai dengan teori yang dikemukakan AJM Ligtenberg tahun 2006 yang menyatakan bahwa meskipun sekresi saliva terhambat oleh efek mentol dari sediaan pasta gigi namun tetap terjadi kenaikan $\mathrm{pH}$ saliva setelah menggunakan pasta gigi dengan sensasi mentol. ${ }^{7}$ Meskipun efek mentol menghalangi sekresi saliva, $\mathrm{pH}$ saliva tetap mengalami kenaikan karena didukung oleh faktor jumlah presentasi sorbitol dalam sediaan pasta gigi gel dengan konsentrasi $70 \%$ sorbitol. Sorbitol memiliki fungsi untuk meningkatkan sekresi saliva di rongga mulut yang nantinya ketika sekresi saliva meningkat akan berdampak kepada kenaikan $\mathrm{pH}$ saliva. ${ }^{6}$ Rata-rata $\mathrm{pH}$ saliva pada menit 
ke-10 setelah sampel menggunakan pasta gigi sediaan gel adalah 7,09. Meskipun mengalami kenaikan, tetapi tidak terjadi perubahan $\mathrm{pH}$ saliva yang signifikan pada menit ke-10 jika dibandingkan dengan $\mathrm{pH}$ saliva sebelum sampel menggunakan pasta gigi sediaan gel dan setelah menit ke-5. Rata-rata $\mathrm{pH}$ saliva pada menit ke30 setelah sampel menggunakan pasta gigi sediaan gel adalah 7,14. $\mathrm{pH}$ saliva pada menit ke-30 ini juga tidak mengalami perubahan yang signifikan jika dibandingkan dengan $\mathrm{pH}$ saliva sebelum sampel menggunakan pasta gigi sediaan gel dan setelah menggunakan sediaan gel pada menit ke-5 dan ke-10. Rata-rata $\mathrm{pH}$ saliva pada menit ke-60 setelah sampel menggunakan pasta gigi sediaan gel adalah 7,06. $\mathrm{pH}$ saliva pada menit ke-60 ini juga tidak mengalami perubahan yang signifikan jika dibandingkan dengan $\mathrm{pH}$ saliva sebelum sampel menggunakan pasta gigi sediaan gel dan setelah menggunakannya pada menit ke-5 dan ke-10 dan ke-30. Namun dari data yang diperoleh diketahui bahwa dari menit ke-5 setelah menggosok gigi sampai menit ke 60 terjadi penurunan $\mathrm{pH}$ saliva menuju ke $\mathrm{pH}$ normal saliva semula. Hal ini sesuai dengan penelitian yang dilakukan oleh AJM Ligtenberg yang menunjukan hasil bahwa setelah menggosok gigi $\mathrm{pH}$ saliva rongga mulut akan meningkat, namun akan mengalami penurunan kembali kearah $\mathrm{pH}$ saliva normal dalam 60 menit. $^{7}$ Penelitian lain juga menunjukkan bahwa akan terjadi kenaikan $\mathrm{pH}$ saliva setelah 5 menit karena diberikan rangsangan mekanis, namun setelah 30-60 menit akan kembali kepada keadaan normal. ${ }^{9}$

Rata-rata $\mathrm{pH}$ saliva sebelum sampel menggunakan pasta gigi sediaan pasta adalah 7,16. Hal ini juga sesuai dengan teori yang menyatakan bahwa $\mathrm{pH}$ saliva dalam keadaan normal berkisar antara 5,6-7,0 dengan rata-rata $\mathrm{pH} 6,7 .^{9}$ Rata-rata $\mathrm{pH}$ saliva pada menit ke-5 setelah sampel menggunakan pasta gigi sediaan pasta adalah 7,10. $\mathrm{pH}$ saliva pada menit ke-5 tidak mengalami penurunan yang signifikan dari $\mathrm{pH}$ saliva sebelum sampel menggunakan pasta gigi sediaan pasta. Rata-rata $\mathrm{pH}$ saliva pada menit ke10 setelah sampel menggunakan pasta gigi sediaan pasta adalah 7,22. $\mathrm{pH}$ saliva pada menit ke-10 ini juga tidak mengalami kenaikan yang signifikan dari $\mathrm{pH}$ saliva sebelum dan setelah 5 menit sampel menggunakan pasta gigi sediaan pasta.

Rata-rata $\mathrm{pH}$ saliva pada menit ke-30 setelah sampel menggunakan pasta gigi sediaan pasta adalah 7,11. $\mathrm{pH}$ saliva pada menit ke-30 tidak terjadi perubahan yang signifikan dari $\mathrm{pH}$ saliva pada menit 
ke-5 dan menit ke-10 setelah sampel menggunakan pasta gigi sediaan pasta. Rata-rata $\mathrm{pH}$ saliva pada menit ke-60 setelah sampel menggunakan pasta gigi sediaan pasta adalah 7,11. pH saliva pada menit ke- 60 mengalami tidak perubahan yang signifikan dari $\mathrm{pH}$ saliva sebelum menggunakan sediaan pasta dan pada menit ke-5 dan menit ke-10 dan ke-30 setelah sampel menggunakan pasta gigi sediaan pasta. Terjadinya kenaikan dan penurunan yang tidak signifikan ini sesuai dengan hasil penelitian AJM Ligtenberg yang menunjukan bahwa pasta gigi sediaan pasta tanpa efek mentol lebih stabil dalam mempertahankan $\mathrm{pH}$ dan kapasitas penyangga saliva kearah $\mathrm{pH}$ normal. ${ }^{7}$

Selisih antara $\mathrm{pH}$ saliva setelah menggunakan kedua jenis sediaan pasta gigi pada menit ke-5 dan sebelum menggunakan kedua jenis sediaan pasta gigi menunjukkan terjadinya perbedaan yang signifikan. Hasil ini menunjukkan bahwa $\mathrm{pH}$ saliva setelah menggunakan pasta gigi sediaan gel pada menit ke-5 mengalami kenaikan yang signifikan jika dibandingkan dengan $\mathrm{pH}$ saliva setelah menggunakan pasta gigi sediaan pasta yang mengalami penurunan. Selain itu, selisih antara $\mathrm{Ph}$ saliva setelah menggunakan kedua jenis sediaan pada menit ke-10 dan menit ke-5 juga menunjukkan perbedaan yang signifikan. Sediaan gel mengalami penurununan sedangkan sediaan pasta mengalami kenaikan $\mathrm{pH}$ saliva. Hal ini sesuai dengan penelitian yang dilakukan oleh AJM Ligtenberg yang menyimpulkan bahwa meskipun pasta gigi sediaan gel dapat meningkatkan $\mathrm{pH}$ saliva pada 5 menit pertama, namun kemampuan untuk mempertahankan $\mathrm{pH}$ saliva sebelum kembali ke keadaan normalnya kurang optimal dibandingkan dengan pasta gigi sediaan pasta yang dapat menjaga konsistensi $\mathrm{pH}$ dan kapasitas penyangga saliva sampai 60 menit setelah menggosok gigi. ${ }^{7}$ Hal ini juga didukung oleh penelitian di India tahun 2013 yang menunjukan bahwa sediaan pasta memiliki pH yang lebih basa pada sediaan gel dan nantinya akan memberikan efek terhadap $\mathrm{pH}$ rongga mulut ${ }^{6}$ Sediaan pasta gigi gel dengan pasta mengandung komposisi yang hamper sama tetapi terdapat perbedaan konsentrasi dan zat tambahan didalamnya. Pasta gigi sediaan gel memiliki presentase humektan mencapai $80 \%$ dari total sediaan sedangkan sediaan pasta hanya memiliki presentase humektan sekitar 40-60 \%. ${ }^{5}$ Humektan yang digunakan biasanya adalah sorbitol. Sorbitol memiliki efek meningkatkan laju alir saliva yang akan dapat menyebabkan 
peningkatan kapasitas penyangga saliva sehingga saliva dalam rongga mulut akan bersifat lebih basa. ${ }^{4}$ Zat tambahan yang diberikan dalam sediaan pasta gigi juga dapat mempengaruhi $\mathrm{pH}$ saliva pengguna setelah menggosok gigi seperti penambahan sensai segar atau mentol. Penambahan sensasi mentol ini dapat menyebabkan pengurangan jumlah sekresi saliva dalam mulut karena efek anastesi lokal sementara yang ditimbulkan sehingga kurang optimumnya $\mathrm{pH}$ saliva yang didapat dibandingkan dengan sediaan tanpa penambahan efek sensasi segar atau mentol. $^{7}$

\section{KESIMPULAN}

Hasil penelitian ini menunjukan bahwa terdapat perbedaan efektivitas mempertahankan $\mathrm{pH}$ saliva pada menit ke 5 setelah menggunakan pasta gigi sediaan gel dengan pasta dimana pada sediaan gel mengalami kenaikan dan pada sediaan pasta mengalami penurunan $\mathrm{pH}$ saliva dan pada menit ke 10 gel dengan pasta dimana pada sediaan pasta mengalami kenaikan dan pada sediaan gel mengalami penurunan $\mathrm{pH}$ saliva.

\section{KEPUSTAKAAN}

1. Pratiwi, I. 2009. Uji Antibakteri Ekstrak Kasar Daun Acalypha indica terhadap Bakteri Salmonella choleraesuis dan Salmonella typhimurium. Surakarta : Jurusan Biologi FMIPA UNS.
2. Poucher, J. 2000. Poucher's Perfumes, Cosmetics and Soaps. Edisi Kesepuluh.London: Kluwer Academic Publisher. Hal. 206, 210.

3. Y. Herdiyanti, I.S Sasmita. 2010. Pengggunaan Fluor dalam Kedokteran Gigi. FKG UNPAD.

4. Sari, Ni Yoman Gemini. 2011.Permen Karet Xylitol yang Dikunyah 5 Menit Meningkatkan dan Mempertahakan $\mathrm{pH}$ Saliva Perokok Selama 3 Jam. Denpasar: Universitas Udayana.

5. Mitsui, T. Phd., 1997. New cosmetics science, Elsevier: Amsterdam.

6. Teki K, Bhat R. 2013. Estimation of the Component in Oral Care products Available in Indian Market - Part II : Toothpaste. Oral Care R \& D Unit, Kemwell Biopharma Private Limited, Bangalore, India. International Journal of Pharmaceutical and Chemical Sciences; 2013: 2 (2), 705-712.

7. Ligtenberg AJM, Brand HS, Bots GP, Amerongen AVN. 2006. The Effect of Toothbrushing on Secretion Rate, $p H$ and Buffering Capacity of Saliva. Int Dent Hygiene: 4 : 104-105.

8. Setia R , Handajani J. 2010. Mengkonsumsi minuman beralkohol dapat menurunkan derajat keasaman dan volume saliva. DENTIKA: 15(1), 16, 18.

9. Handajani J, Rini MP. 2010. Pemakaian kontrasepsi pil dan suntik menaikkan $\mathrm{pH}$ dan volume saliva. DENTIKA: 15(1), 1 .

10. Almeida PV, Gregio AM, Machado MAN, Lima AAS, Azevedo LR. 2008. Saliva Composition and Function. J Contemp Dent Pract: 9(3), 2-5.

11. Nutt JB, Susan EB. 2013. Effect Of Toothpaste Formulations On The Number Of Viable Bacteria Left On Toothbrushes Following Routine Brushing. Rivier Acadenic Journal: 9(1), 2.

12. Harry.R.G. 1973. Harry's cosmetology, $6^{\text {th }}$ edition, leonard hill books. New York.

13. George M. Howard. 1974. Perfume, cosmetics and soaps, Vol.III, eight edition, Chapman and Hall, London.

14. Lieberman, H. A., Rieger, M. M., dan Banker, G. S., 1996. Pharmaceutical Dosage Forms: Dispers System, Vol. 2, 
Second Edition, 397, 400-401, Mariel Dekker, Inc., New York Nair ASU, Rooban T, Kannan R. Saliva and dental practice. $J$ NTR Univ Health Sci; 2012: 1(2), 73.

15. Hidayani TA, Handajani J. 2010. Efek Merokok Terhadap Status Ph Dan Volume Saliva Pada Laki-Laki Usia Dewasa dan Usia Lanjut. DENTIKA; 2010: 15(2), 146,148 .

16. Maldupa I, Anda B, Inga R, Anna M. 2012. Evidence Base Toothpaste Classification, According To Certain Characteristics Of Their Chemical Compotition.Baltic Dental and Maxillofacial Journal; 2012: 14(1), 13, 16-9.

17. Nigam AG, Jaiswal JN, Murthy RC, Pandey RK. 2009. Estimation Of Fluoride Release From Various Dental Materials In Different Media-An In Vitro Study. J Clin Pediatr Dent; 2009: 2(1), 1.

18. Tschoppe P, Hendrik ML. Effect of regular and highly fluoridated toothpastes in combination with saliva substitutes on artificial enamel caries lesions differing in mineral content. Archives of oral biology. Available from http://www.sdclucknow.com/Journal2012/9 3. Accessed December 6, 2015.

19. Santi C, Sri R, Cut RR. 2010. Pengaruh Bahan Antikaries Bebrapa Tanaman Herbal Yang Dikombinasikan Dengan Pasta Gigi Yang Mengandung Fluoride Terhadap Pertumbuhan Streptococcus Mutans Secara In Vitro. DENTIKA; 2010: 15(2), 136.

20. Talha WM, Mana E, Ola MO, Somaiya AE. 2013. The Effect Of Miswak And Fluoride Toothpastes On Dental Plaque, A Comparative Clinical And Microbiology Study. Nature and Science; 2013: 11(9), 3.

21. Agtini Md, Sintawati, Tjahja I. 2005. Fluor dan Kesehatan Gigi. Media Litbang Kesehatan; 2005: 15(2), 28.

22. Dabrowska E, Letko M, Roszkowska JW, Letko R, Jamiolkowski J. 2005. Effect Of Fluoride Preparations On The Activity Of Human Salivary Cathepsin C. RoczAkad Med Bialymst; 2005: 50, 162.

23. Bardow A, Lagerloff, Nauntofte B, Tenovuo J. 2008. The role of saliva. Dental Caries The disease and Its Clinical Management. $2^{\text {nd }}$ ed. Australia: Blackwell munksgaard Ltd.; 2008. pp. 203.
24. Limeback H, Colin R. Fluoride therapy. 2012 Comprehensive Preventive Dentistry. USA: John Wiley and Sons Ltd.; 2012. pp. 257-8.

25. Kidd, E.A.M., Bechal, S.J. 1992. DasarDasar Karies Penyakit dan Penanggulanganya. Alih Bahasa : Narlan Sumawinata dan Safrida Faruk.

EGC. Jakarta. Hal.2,65-67.

26. Amerongen, A.V.N. 1991. Ludah dan Kelenjar Ludah. Arti Bagi Kesehatan Gigi. Alih Bahasa : Prof.drg.Rafiah Abyono. Ed1.UGM. Yogyakarta. Hal.2,3,23,36,37.

27. Kelley, L.L., Petersen, C. M. 2007. Sectional Anatomy for Imaging Professionals. Second Edition. Mosby. Elsevier. USA. Hal.242.

28. Guyton, A.C., Hall, J.E. 2008. Buku Ajar Fisiologi Kedokteran. Alih Bahasa : Irawati dll. Cetakan-1. EGC. Jakarta. Hal.835-836.

29. Sherwood, L. 2001. Fisologi Manusia. Alih Bahasa: Brahm U. Pendit. Ed-2. EGC. Jakarta. Hal.545-548.

30. Snell, R. S. 2004. Clinical Anatomy . Ed-7. Lippicot Williams \& Wilkins. USA. Hal.773-788.

31. Snell, R.S. 1997. Anatomi Klinik. Untuk Mahasiswa Kedokteran. Alih Bahasa : dr. Jan Tambayong. Bag-3. Ed-3. EGC. Jakarta. Hal.10.

32. Marieb, E.,N., 2004, Human Anatomy \& Physilogy. Sixth Adition. Pearson Benjamin Cummings. Hal.890-891.

33. Martin, T. 2008. The Effects of Smoking on Human Health Smoking Effect. [cited 2010 mar. 17] Available from: http:// quitsmoking.about.com.

34. Roukema, P.A.M. 1993. Ilmu Kedokteran Gigi Pencegahan. Penerjemah: Sutatmi Suryo. Cetakan I. UGM. Yogyakarta. Hal.114-123.

35. Tumilasci, O.R., Cardoso, E.M.L., Contreras, L.N., Belforte, B., Arregger, A.L., Ostuni, M.A. 2006. Standardization of Simple Method to Study Whole Saliva: Clinical Use in Difefrent Pathologies. Acta Odontol Latinoam; 19 (2): 47-51.

36. University of Newcastle Dental School. 2009. Bite-Sized Tutorials: Salivary Buffering, Bicarbonate \& $p H$. Dirujuk 9 
Februari, 2016 dari http://ncl.ac.uk/dental/oralbiol/oralenv/tutor ials/bicarbonate.htm 